\title{
Empirical Investigation on the Performance of
}

\section{the Malaysian Real Estate Investment Trusts in Pre-Crisis, During Crisis and Post-Crisis Period}

\author{
Ahmad Husni Hamzah \\ Department of Finance and Banking \\ Faculty of Business Management and Accountancy \\ University Darul Iman Malaysia, KUSZA Campus, 21300 Kuala Terengganu, Malaysia \\ Tel: 60-9-665-3790Ｅ-mail: ahmadhusni@udm.edu.my \\ Mohammad Badri Rozali \\ College of Business \\ University Utara Malaysia, 06010 Sintok, Kedah Darul Aman \\ Tel: 60-4-928-6401 E-mail: badri@uum.edu.my \\ Izah Mohd Tahir (Corresponding Author) \\ Department of Finance and Banking \\ Faculty of Business Management and Accountancy \\ University Darul Iman Malaysia, KUSZA Campus, 21300 Kuala Terengganu, Malaysia \\ Tel: 60-9-665-3863E-mail: izah@udm.edu.my
}

\begin{abstract}
This study examines the performance of Real Estate Investment Trusts (REITs) or listed property trusts in Malaysia using three standard performance measurement methods (Sharpe Index, Treynor Index and Jensen Index) for 1995 to 2005 . In addition, it investigates the degree of systematic risks of REITs and to determine whether REITs give higher returns than the market portfolio. The results indicate that the risk-adjusted performance of REITs vary over time. REITs in general outperformed the market portfolio during the 1997-1998 financial crisis but underperformed in the pre-crisis (1995-1997) and post-crisis period (1998-2005). This study also found that the average systematic risks of REITs were slightly higher than the market portfolio during the pre-crisis and crisis period but were significantly lower in the post-crisis period.
\end{abstract}

Keywords: Real Estate Investment Trusts, Risk-adjusted Performance, Systematic Risk, Malaysia

\section{Introduction}

Real estate investment trusts or REITs are collective investment schemes where funds are pooled and primarily invested in real estate assets and other real estate related assets. Real estate assets may consist of residential or commercial buildings, retail or industrial lots, lodgings/resorts, hospitals/health care facilities, self-storage facilities and specialty-built buildings. Examples of real estate related assets are shares in public-listed property companies and listed or unlisted debt securities of property companies. Subject to the investment limits prescribed by a regulatory body, REITs are also permitted to invest in non-real estate related assets, asset-backed securities and liquid assets. REITs, which may be listed or unlisted, generate investment returns from the rental income collected from tenants plus any capital appreciation arising from holding the real estate over the period. Investors in REITs, called unit holders, receive their returns in the form of dividends and/or capital gains for the holding period.

Real estate investment trusts (REITs) are commonly known as listed property trusts in Malaysia. In Asia, Malaysia was the first to have listed property trusts in 1989. The Asian economic crisis during the 1997-1998 period, had significantly contributed to the development of REITs in other Asian countries. The REIT market took off later in Japan and Singapore in 2001 and 2002 respectively. South Korea established its REIT legislation in 2001 while Taiwan launched its first REIT in 2004. Hong Kong was the latest to introduce a listed 
REIT in 2005. While Japan has the most developed REIT market, Singapore is widely considered to be the most dynamic REIT market among other Asian countries.

Many researchers have studied REIT performance in developed markets, especially in the US, since the late 1970s. Findings on the US REIT performance have been mixed relative to the stock market portfolio. However, few studies have been conducted on this topic in Malaysia. Findings by Kok \& Khoo (1995) suggested inconsistent risk-adjusted performance and systematic risk while Newell, Ting \& Acheampong (2002) discovered unfavourable risk-adjusted performance.

The government has recently amended and introduced new legislative measures to accelerate the growth of the REIT industry in Malaysia and promote REITs as a viable investment vehicle for industry players and investors. The motivation of this study is to provide empirical information pertaining to the historical performance and the risk associated with the investment in REITs. Therefore, this paper aims to expand on existing literature by providing evidence on the risk-return performance of REITs over a 10-year period in each economic cycle, namely pre-crisis, during crisis and post-crisis.

The objectives of the study are:

(a) to evaluate the performance of REITs based on three standard performance measurement methods, namely Sharpe Index, Treynor Index and Jensen Index;

(b) to examine the systematic risk of REITs; and

(c) to investigate whether REITs give higher returns than the market portfolio, the Kuala Lumpur Composite Index (KLCI), and the relevant sector benchmark, Kuala Lumpur Properties Index (KLPI), respectively.

This article is organized as follows: Section 2 overviews the development of REITs in Malaysia followed by empirical evidence from previous research. Section 4 discusses the data and methodology and Section 5 presents the results, followed by the conclusion.

\section{Development of REITs in Malaysia}

\subsection{Regulatory Framework}

Malaysia was the first country in Asia to introduce legislation to permit the formation of listed property trusts. In 1986, Bank Negara Malaysia (the Central Bank of Malaysia) approved the regulatory framework for listed property trusts where the principal governing their establishment and operation was the Companies Act 1965 and the Securities Industry Act 1983. Specific guidelines on property trust funds were introduced by the Securities Commission in 1991 and later revised in 1995.

In 1999, the Securities Commission embarked upon a consultation process in relation to property trust funds vis-à-vis the likes of similar products in other jurisdictions, such as REITs in the United States and property funds in Singapore. It issued a Consultation Paper on Property Trust Fund and Consultation Paper on Property Trust Funds and Real Estate Investment Trusts in 1999 and 2002 respectively.

Pursuant to the Finance Act 2004, which was gazetted in December 2004, REITs will enjoy a tax treatment as follows:

(a) REIT to be exempted from tax on income distributed to its unit holders whereas the undistributed income will be taxed at $28 \%$;

(b) Income distributed to unit holders will be taxed at their respective taxes. However, for non-residents, the tax payable at $28 \%$ will be withheld by REIT; and

(c) The accumulated income that has been taxed and subsequently distributed is eligible for tax credit in the hand of unit holders.

Furthermore, REITs under the Finance Act 2004 enjoy stamp duty exemptions on all instruments of transfer of real property. Property owners who sell their properties to REITs are also exempted from real property gains tax. However, the filing obligations imposed under the Stamp Act 1949 and the Real Property Gains Tax 1976, are still required to be adhered to.

On January 3, 2005, the Securities Commission issued the new Guidelines on Real Estate Investment Trusts to govern the operation and administration of REITs in Malaysia. The amended guidelines have generated a lot of excitement and discussion among industry players, with a number of them, especially those with sizeable investment properties, seriously considering injecting their assets into such trusts. 
The key features of the new guidelines, which are a major improvement from the old guidelines, include the following:

- Liberalization of the borrowing limit for a REIT;

- Relaxation of rules on acquisitions of leasehold properties;

- Flexibility in the acquisition of real estate that is encumbered by financial charges;

- Eligibility requirements for management companies that manage REITs have been streamlined;

- Introduction of a declaratory approach in the establishment of REITs; and

- Enhancement in the amount of exposure and reporting required which is consistent with international standards.

On November 22, 2005, the Securities Commission issued the Guidelines on Islamic Real Estate Investment Trusts (Islamic REITs) to facilitate further development of new Islamic capital market products. Malaysia was the first jurisdiction in the global Islamic financial sector to issue such guidelines and had set a global benchmark for the development of Islamic REITs. The Islamic REITs guidelines complemented the existing guidelines on conventional REITs. Syariah (Islamic jurisprudence) compliance criteria are provided in the guidelines to guide management companies in their activities relating to REITs, including the types of Syariah permissible and non-permissible rental and investment activities.

\subsection{Industry Growth}

The first Malaysian listed property trust, Arab Malaysian First Property Trust, was launched in September 1989. The second listed property trust was First Malaysian Property Trust, established in November 1989, and followed by the third listed property trust, Amanah Harta Tanah PNB, which commenced in December 1990. The fourth property trust was the unlisted Mayban Property Trust Fund One launched in 1990. There was no listed property trusts issued until Mayban Property Trust Fund One was listed on the KLSE in June 1997 and known as Amanah Harta Tanah PNB 2. The First Malaysian Property Trust, however, ceased its listing in July 2002. As at the end of April 2005, only three property trusts were listed on the Bursa Malaysia comprising AmFirst Property Trust (formerly Arab Malaysian First Property Trust), Amanah Harta Tanah PNB and Amanah Harta Tanah PNB 2.

Following the introduction of the new Guidelines on Real Estate Investment Trusts, Axis Real Estate Investment Trust was the first to be listed on Bursa Malaysia on July 29, 2005. Next, Starhill Real Estate Investment Trust, the country's largest REITS was listed on December 16, 2005, followed by UOA Real Estate Investment Trust on December 30, 2005. Table 1 presents the list of real estate investment trusts as at May 2009.

\section{Empirical Evidence from Previous Research}

The literatures on empirical investigation of REIT performance, especially in the US REIT industry are extensive. Indeed, dramatic events related to the REIT industry have attracted many studies on this topic. Research findings on the REIT performance have been mixed and inconclusive. Some studies suggested that the performance of REIT stocks was worse than, or comparable to, the stock market portfolio. Others, however, discovered that REITs, especially equity REITs, outperformed the stock market portfolio. In addition, it is generally found that the results from REIT performance studies seem to be highly sensitive to the sample period studied.

Smith \& Shulman (1976) made a comparison among the performance of 16 REITs to the S\&P 500 index, savings accounts, and 15 closed-end funds over the 1963-1974 period. They discovered that equity REITs outperformed savings account and the S\&P index for the 1963-1973 period. However, the poor performance of REITS stocks in 1974 resulted in their REITS sample underperforming the S\&P index for the whole 1963-1974 period. Kuhle \& Walther (1986) found that REITs performed poorly during the mid-1970s. When comparing both the CAPM-based Jensen indexes and the APT-based Jensen indexes on 16 equity REITs and 20 mortgage REITs over the 1973-1982 period, Titman \& Warga (1986) concluded that the performance of REIT stocks was not significantly different from that of the market portfolio. Another study by Goebel \& Kim (1989) suggested that REITs underperformed compared to the S\&P index over the 1984-1987 period. Howe \& Shilling (1990) also found that REITs underperformed the CSRP equally weighted index over the 1973-1987 period.

However, the findings from the studies on the REIT performance over the period between the late 1970s and early 1980s generally indicated that the performance of the REIT industry was similar or superior to that of the market portfolio. Burns \& Epley (1982) found that mixed-asset portfolios containing 35 survivor REITs outperformed the S\&P index and single asset portfolios over the 1973-1985 period. Kuhle \& Walther (1986) 
discovered that REITs outperformed the S \& P index in 1977-1984. Similarly, Sagalyn (1990) found that survivor equity REITs outperformed the S\&P index over the 1973-1987 period.

Han \& Liang (1995) examined the performance of 255 US REIT stocks over the 1970-1993 period. The sample REIT stocks were divided into 3 subgroups: equity REITs, hybrid REITs and mortgage REITs. Their findings suggested that the performance of the REIT portfolios was consistent with the Security Market Line over the 1970-1993 period. However, the REIT performance varied over the period and the use of unrepresentative S\&P 500 index as a performance benchmark tends to overstate the REIT performance. They also found survivor REITs performed better than the overall REIT population.

In Singapore, Liow (2001) examined the long-term investment performance of Singapore real estate and property stocks and found that real estate outperformed property stocks on a risk-adjusted basis. The study also found that risk-adjusted investment performance for residential properties remained superior to performance for other real estate types and property stocks.

In the Malaysian context, published evidence on the performance of REITs is very limited. Kok \& Khoo (1995) examined the performance and the systematic risk of three listed property trusts, namely Arab Malaysian First Property Trust, First Malaysia Property Trust and Amanah Harta Tanah PNB, over the January 1991-April 1995 period using the Sharpe Index, Treynor Index and Jensen Index. They further divided the period into three sub-period: rising market (January 1991-November 1993), over-speculated market (January 1991-March 1994) and declining market (January 1994-April 1995). Their findings concluded that First Malaysia Property Trust outperformed other listed property trusts and performed as well as the market portfolio over the period. The listed property trusts generally performed better than the market in a falling market but worse than the market in a rising market. The listed property trusts did not give consistent performances. The systematic risks of the listed property trusts were low before the period of over-speculation. However, after the period of over-speculation, the systematic risks were higher than those of the market.

Newell, Ting \& Acheampong (2002) analyzed the performance of four listed property trusts, namely Arab Malaysian First Property Trust, First Malaysia Property Trust, Amanah Harta Tanah PNB and Mayban Property Trust Fund One (Amanah Harta Tanah PNB 2), over the 1991-2000 period. They utilized average annual returns, standard deviations and coefficient of variations to measure returns, risks and risk-adjusted performances respectively. Based on the average annual return measures, they found that only Amanah Harta Tanah PNB outperformed the Kuala Lumpur Composite Index, the Kuala Lumpur Properties Index and the Kuala Lumpur Office Property Index over the period. The risks, as measured by standard deviation, for three of the listed property trusts (First Malaysia Property Trust, Amanah Harta Tanah PNB and Mayban Property Trust Fund One (Amanah Harta Tanah PNB 2)) were more than the overall stock market risk and significantly above the office real estate risk. They also concluded that based on a coefficient of variation measure, each of the listed property trusts significantly underperformed compared to the Kuala Lumpur Composite Index and real estate companies sector.

\section{Data and Methodology}

The sample data consists of four Malaysian REITs, namely AmFirst Property Trust (AMFPT), First Malaysia Property Trust (FMPT), Amanah Harta Tanah PNB (AHP) and Amanah Harta Tanah PNB 2 (AHP2). Monthly returns adjusted for dividends and bonuses distributed to unit holders were computed for the 10-year period from April 1995 to April 2005. The period was chosen since we are able to have complete data and the financial crisis of 1997 made it possible for us to divide the periods into three sub periods; pre-crisis, during crisis and post-crisis. Data for FMPT ends in March 2002 as it was delisted from the Kuala Lumpur Stock Exchange (KLSE), while data for AMFPT commences from June 1997 when it assumed listing of Mayban Property Trust Fund One.

For the purpose of this study, we use the returns on the Kuala Lumpur Composite Index (KLCI) as a proxy for returns on the market portfolio even though other benchmark such as Morgan Stanley Asian Stock market Index can also be used. The risk-free rate was proxied by the 3-month Treasury Bills. In addition, the returns on the Kuala Lumpur Properties Index (KLPI) were utilized as a sector proxy benchmark. Based on the economic cycle throughout the period, the analysis period is further classified into three different sub-period of the 1997 financial crisis, as follows: (1) Pre-crisis (April 1995-June 1997); (2) During crisis (July 1997-September 1998); and (3) Post-crisis (October 1998-April 2005). The measurement of returns on the REITS's is derived from two components, namely income and capital gain. The rate of returns for each REITS is calculated as follows:

$$
\mathrm{R}_{\mathrm{p}}=\frac{\mathrm{P}_{\mathrm{t}}-\mathrm{P}_{\mathrm{t}-1}+\mathrm{D}_{\mathrm{t}}}{\mathrm{P}_{\mathrm{t}-1}}
$$


where $R_{p}$ is total return of a portfolio (individual REIT), $P_{t}$ is price at time $t, P_{t-1}$ is price one period before time $t$ and $\mathrm{D}_{\mathrm{t}}$ is dividend or cash disbursement at time $\mathrm{t}$.

The return on the benchmark market index is measured as follows:

$\frac{\mathrm{R}_{\mathrm{m}}=\mathrm{I}_{\mathrm{t}}-\mathrm{I}_{\mathrm{t}-1}+\mathrm{D}_{\mathrm{t}}}{\mathrm{I}_{\mathrm{t}-1}}$

where $R_{m}$ is return on market index, $I_{t}$ is market index value in time period $t, I_{t-1}$ is market index value one period before time $t$ and $D_{t}$ is dividend or cash disbursement at time $t$.

In this study, three standard performance measurement methods, namely Sharpe Index, Treynor Index and Jensen Alpha Index are employed to evaluate the performance of REITs.

The Sharpe Index (1966) measures investment performance using total risk:

$$
\text { SI }=\frac{\mathrm{R}_{\mathrm{p}}-\mathrm{R}_{\mathrm{f}}}{\sigma_{\mathrm{p}}}
$$

where SI is Sharpe Index, $\mathrm{R}_{\mathrm{p}}$ is the return for portfolio, $\mathrm{R}_{\mathrm{f}}$ is the risk-free rate of return and $\sigma_{\mathrm{p}}$ is the standard deviation of returns for portfolio.

Due to the bias in estimation of the standard deviation, Sharpe index has been modified by Jobson \& Korkie (1981) to become Adjusted Sharpe Index as follows:

no. of observations $(\mathrm{N})$

$$
\text { ASI } \quad=\text { SI } x
$$

no. of observations $(\mathrm{N})+0.75$

Treynor (1965) developed a measure of investment performance using systematic risk:

$$
\mathrm{TI}=\frac{\mathrm{R}_{\mathrm{p}}-\mathrm{R}_{\mathrm{f}}}{\beta_{\mathrm{p}}}
$$

where TI is the Treynor Index and $\beta_{\mathrm{p}}$ is the Systematic risk for portfolio.

Jensen (1968) developed an ex-post alpha measure to determine the size of excess returns achieved by a portfolio.

$$
\begin{aligned}
& \mathrm{JI}=\left(\mathrm{R}_{\mathrm{p}}-\mathrm{R}_{\mathrm{t}}\right)-\left[\beta_{\mathrm{p}}\left(\mathrm{R}_{\mathrm{m}}-\mathrm{R}_{\mathrm{f}}\right)\right] \\
& \mathrm{R}_{\mathrm{pt}}-\mathrm{R}_{\mathrm{ft}}=\alpha_{\mathrm{p}}+\beta_{\mathrm{p}}\left(\mathrm{R}_{\mathrm{mt}}-\mathrm{R}_{\mathrm{ft}}\right)+\mathrm{e}_{\mathrm{pt}}
\end{aligned}
$$

To adjust for different levels of systematic risk factors, an Adjusted Jensen Alpha Index is computed as follows:

$$
\text { AJI }=\frac{\text { Jensen Alpha Index }(\mathrm{JI})}{\text { Beta of the portfolio }\left(\beta_{\mathrm{p}}\right)}
$$

The beta coefficient, which measures the systematic risk of REIT portfolio, is computed by regressing the returns of each REITS on the returns of the market portfolio as follows:

$$
\mathrm{R}_{\mathrm{pt}}=\alpha_{\mathrm{p}}+\beta_{\mathrm{p}} \mathrm{R}_{\mathrm{mt}}+\mathrm{e}_{\mathrm{pt}}
$$

where $\alpha_{p}$ is a constant term, $\beta_{p}$ is the beta coefficient of the portfolio and $R_{m t}$ is the returns on the market portfolio.

\section{Empirical Results}

The values of the Adjusted Sharpe Index for the four REITs in each economic cycle are presented in Table 2. All REITs underperformed the KLCI while two of three REITs (except AMFPT) underperformed the KLPI in the pre-crisis. However, all REITs outperformed both the KLCI and KLPI during the crisis. In post-crisis, all REITs and two of three REITs (except AHP) underperformed the KLCI and KLPI respectively. 
Table 3 demonstrates the values of the Treynor Index for the REITs and the market portfolio. In pre-crisis, all REITs recorded lower values than that of the KLCI, signaling underperformance. During the crisis, all REITs had higher values than that of the KLCI indicating they outperformed the market portfolio. In post-crisis, all REITs underperformed the KLCI. If compared against KLPI in each economic condition, two of three REITs (except AMFPT) underperformed the KLPI in pre-crisis. Three of four REITs (except AHP) outperformed while two of three (except AHP) underperformed the KLPI during the crisis and post-crisis period respectively. Based on relative investment performance, both the Adjusted Sharpe Index and Treynor Index of the REITs generally produce similar results. Furthermore, the average values of Adjusted Sharpe Index and Treynor Index indicate similar relative performance against the KLCI and KLPI respectively.

Table 4 presents the values of the Adjusted Jensen Alpha Index for all REITs. During the pre-crisis and post-crisis period, all REITs have negative index values, thereby indicating poorer performance than the market as represented by the KLCI. However, all REITs produce better performance than the market during the crisis. If compared to the sector benchmark (KLPI), the results are relatively similar. In both the pre-crisis and post-crisis period, all REITs (except AMFPT in the pre-crisis and AHP in the post-crisis period) have poorer performance than the KLPI. During the crisis, all REITs (except AHP) have positive index values and better performance than the KLPI.

Tables 5(a) and 5(b) show the beta values for all REITs in each of the economic cycles. In the pre-crisis, mostly all REITs recorded higher betas in the range of 0.896 to 1.259 (against KLCI) and 0.942 to 1.255 (against KLPI) respectively. In fact, the average beta is greater than 1.00, possessing slightly higher systematic risk than the market portfolio. During the crisis period, the average betas stand at 1.047 (against KLCI) and 0.833 (against KLPI). However, in the post-crisis, the average betas of all REITs decrease significantly to 0.519 (KLCI) and 0.478 (KLPI), thus indicating lower systematic risks than the market portfolio.

\section{Conclusion}

This study investigated the performance and systematic risk of REITs in Malaysia in different economic cycles. The results indicate that the risk-adjusted performance and systematic risk of REITs varied over time. The Adjusted Sharpe Index and Treynor Index produce similar results in terms of relative investment performance. REITs in general outperformed the market portfolio during the crisis but underperformed in the pre-crisis and post-crisis period. Likewise the Adjusted Jensen Alpha Index suggested that REITs on average generated better performance than the market portfolio during the crisis but recorded poorer performance in the pre-crisis and post-crisis period.

Better performance during the crisis may be explained by the 'lag effect' experienced by the property and construction sectors during the economic cycle transitions. The property sector may not immediately absorb the effect of economic downturn during a crisis period. As such, the economic impact due to recession would take some 'gestation period' before it directly affects the property sectors. Furthermore, the crisis period is a relatively short timeframe. The spillover effect of economic recession would thus be most likely experienced by property sectors in the post-crisis period.

This study found that average systematic risks of REITs were slightly higher than the market portfolio during the pre-crisis and the crisis period. This result may be explained by Kok \& Khoo (1995) who discovered that systematic risks increased after the episode of over-speculation (January 1994 - April 1995). Since this study begins immediately from April 1995, the over-speculation effects may still have been be largely present. The average systematic risks, however, declined significantly in the post-crisis period.

The limitations of this study are the absence of data on the Kuala Lumpur Office Property Index and used Kuala Lumpur Composite Index (KLCI) as a benchmark for returns of the market portfolio. Further study should also use other benchmark such as Morgan Stanley Asian Stock Market. In addition, further research should focus on the comparison between Islamic REITs and non-Islamic REITs. It is hopeful that the empirical findings can help both institutional and retail investors to comprehend the risk-return trade-off and to consider REITs as another viable investment alternative. The study would also benefit the regulatory body in designing a conducive legal framework to enhance the development of the REIT industry in Malaysia.

\section{References}

Burns, W.L. \& Epley, D.R. (1982). “The Performance of Portfolio of REITs and Stocks". Journal of Portfolio Management, Winter, 37-41.

Goebel, P.R. \& Kim, K.S. (1989). "Performance Evaluation of Finite-Life Real Estate Investment Trusts". Journal of Real Estate Research, 4:2, 57-69. 
Han, J. \& Liang, Y. (1995). “The Historical Performance of Real Estate Investment Trusts". Journal of Real Estate Research, 235-262.

Howe, J.S. \& Shilling, J.D. (1990). "REITS Advisor Performance". AREUEA Journal, 18:4, 479-500.

Jensen, M.C. (1972). "The Performance of Mutual Funds in the period 1945-1964". Journal of Finance, 23 (2), 389-416.

Jobson, J.D. \& Korkie, B.M. (1981). "Performance Hypothesis Testing with the Sharpe and Treynor Measures". Journal of Finance, 36, September, 889-908.

Kok, K.K. \& Khoo, K.L. (1995). "Performance of Property Trusts in the Kuala Lumpur Stock Exchange". Capital Markets Review, Vol. 3, 1-19.

Kuhle, J.L. \& Walther, C.H. (1986). "REITS vs. Common Stock Investments: An Historical Perspective: A Survey of Performance Results, 1973-1984". Real Estate Finance, 3:1, 477-52.

Liow, K. H. (2001), The long-term investment performance of Singapore real estate and property stocks, Journal of Property Investment \& Finance, vol. 19. No. 2. Pp. 156-174.

Newell, G., Ting, H.K. \& Acheampong, P. (2002). "Listed Property Trusts in Malaysia”. Journal of Real Estate Literature, Vol. 10, 109-118.

Sagalyn, L.B. (1990). "Real Estate Risk and the Business Cycle: Evidence from Security Markets". Journal of Real Estate Research, 5:2, 203-19.

Smith, K.V. \& Shulman, D. (1976). "The Performance of Equity Real Estate Investment Trusts". Financial Analysts Journal, September-October, 61-66.

Securities Commission. Various Guidelines on Listed Property Trusts and Real Estate Investment Trust. Kuala Lumpur.

Sharpe, W.F. (1966). "Mutual Fund Performance". Journal of Business, 39 (1), 119-138.

Titman, S. \& Warga, A. (1986). "Risk and the Performance of the Real Estate Investment Trusts: A Multiple Index Approach”. AREUEA Journal, 14:3, 414-31.

Treynor, J. (1965). "How to Rate Management of Mutual Funds". Harvard Business Review, Vol. 8, January/February, 63-75.

Table 1. List of listed real estate investment trust (As at 31 May 2009)

\begin{tabular}{clll}
\hline No & \multicolumn{1}{c}{ Funds Under Management } & \multicolumn{1}{c}{ Trustee } & \multicolumn{1}{c}{ Management Company } \\
\hline 1 & AmFirst Real Estate Investment Trust & Mayban Trustees Berhad & AmARA REITS Managers Sdn Bhd \\
2 & Axis Real Estate Investment Trust * & OSK Trustees Berhad & Axis REITS Managers Berhad \\
3 & AmanahRaya Real Estate Investment & CIMB Trustee Berhad & AmanahRaya-JMF Asset Management \\
& Trust & & Sdn Bhd \\
4 & Atrium Real Estate Investment Trust & BHLB Trustee Berhad & Atrium REITS Managers Sdn Bhd \\
5 & Al-Hadharah Boustead REITS * & CIMB Trustee Berhad & Boustead REITS Managers Sdn Bhd \\
6 & Al- Aqar KPJ Real Estate Investment & AmanahRaya Trustees Berhad & Damansara REITS Managers Sdn Bhd \\
& Trust* & & \\
7 & Tower Real Estate Investment Trust & AmTrustee Berhad & GLM REITS Management Sdn Bhd \\
8 & Hektar Real Estate Investment Trust & AmTrustee Berhad & Hektar Asset Management Sdn Bhd \\
9 & Starhill Real Estate Investment Trust & Mayban Trustees Berhad & Pintar Projek Sdn Bhd \\
10 & Amanah Harta Tanah PNB & Amanah Raya Berhad & Pelaburan Hartanah Nasional Berhad \\
11 & Amanah Harta Tanah PNB 2 & CIMB Trustee Berhad & Pelaburan Hartanah Nasional Berhad \\
12 & Quill Capita Trust & Mayban Trustees Berhad & Quill Capita Management Sdn Bhd \\
13 & UOA Real Estate Investment Trust & OSK Trustees Berhad & UOA Asset Management Sdn Bhd \\
\hline Note: ${ }^{*}$ Islamic Fund & & \\
Source: Data and Statistics from Securities Commission Malaysia & \\
\hline
\end{tabular}


Table 2. Performance of REITs as measured by Adjusted Sharpe Index

\begin{tabular}{lccc}
\hline & & Time Period & Post-crisis \\
\cline { 2 - 4 } REITs & Pre-crisis & Crisis & 0.0415 \\
AHP & -0.1350 & -0.3211 & -0.0429 \\
AHP2 & - & -0.1864 & -0.0824 \\
AMFPT & -0.0434 & -0.2424 & - \\
\hline FMPT & -0.0701 & -0.1901 & -0.0279 \\
Average & -0.0828 & -0.2350 & 0.1482 \\
Market Portfolio (KLCI) & 0.0189 & -0.4218 & 0.0326 \\
Market Portfolio (KLPI) & -0.0685 & -0.3315 & \\
\hline
\end{tabular}

Table 3. Performance of REITs as measured by Treynor Index (KLCI \& KLPI)

\begin{tabular}{|c|c|c|c|c|c|c|}
\hline \multirow{3}{*}{ REITs } & \multicolumn{6}{|c|}{ Time Period } \\
\hline & \multicolumn{2}{|c|}{ Pre-crisis } & \multicolumn{2}{|c|}{ Crisis } & \multicolumn{2}{|c|}{ Post-crisis } \\
\hline & KLCI & KLPI & KLCI & KLPI & KLCI & KLPI \\
\hline AHP & -0.0112 & -0.0112 & -0.0581 & -0.0835 & 0.0048 & 0.0058 \\
\hline AHP2 & - & - & -0.0346 & -0.0378 & -0.0098 & -0.0108 \\
\hline AMFPT & -0.0038 & -0.0037 & -0.0476 & -0.0530 & -0.0103 & -0.0111 \\
\hline FMPT & -0.0071 & -0.0063 & -0.0362 & -0.0400 & - & - \\
\hline Average & -0.0074 & -0.0071 & -0.0441 & -0.0536 & -0.0051 & -0.0054 \\
\hline Market Portfolio & 0.0008 & -0.0047 & -0.0622 & -0.0721 & 0.0112 & 0.0028 \\
\hline
\end{tabular}

Table 4. Performance of REITs as measured by Adjusted Jensen Alpha Index (KLCI \& KLPI)

\begin{tabular}{lcccccc}
\hline & \multicolumn{7}{c}{ Time Period } \\
\cline { 2 - 7 } REITs & \multicolumn{2}{c}{ Pre-crisis } & \multicolumn{2}{c}{ Crisis } & \multicolumn{2}{c}{ Post-crisis } \\
\cline { 2 - 7 } & KLCI & KLPI & KLCI & KLPI & KLCI & KLPI \\
\hline AHP & -0.0121 & -0.0066 & 0.0041 & -0.0114 & -0.0063 & 0.0030 \\
AHP2 & - & - & 0.0275 & 0.0343 & -0.0438 & -0.0136 \\
AMFPT & -0.0047 & 0.0010 & 0.0146 & 0.0191 & -0.0214 & -0.0140 \\
FMPT & -0.0080 & -0.0016 & 0.0259 & 0.0321 & - & - \\
\hline Average & -0.0083 & -0.0024 & 0.0180 & 0.0185 & -0.0238 & -0.0082 \\
\hline
\end{tabular}

Table 5(a). Systematic Risk (Beta) of REITs (Sub-period KLCI)

\begin{tabular}{lcccccc}
\hline & \multicolumn{7}{c}{ Time Period } \\
\cline { 2 - 7 } REITs & \multicolumn{2}{c}{ Pre-crisis } & \multicolumn{2}{c}{ Crisis } & \multicolumn{2}{c}{ Post-crisis } \\
\cline { 2 - 7 } & (KLCI) & $\boldsymbol{p}$-value & (KLCI) & $\boldsymbol{p}$-value & KLCI) & $\boldsymbol{p}$-value \\
\hline AHP & 1.259 & 0.003 & 1.140 & 0.000 & 0.865 & 0.000 \\
AHP2 & - & - & 0.973 & 0.000 & 0.328 & 0.002 \\
AMFPT & 0.896 & 0.005 & 0.859 & 0.000 & 0.474 & 0.000 \\
FMPT & 0.964 & 0.018 & 1.218 & 0.000 & 0.412 & 0.060 \\
\hline Average & 1.039 & \multicolumn{7}{c}{0.519} & 0.047 \\
\hline
\end{tabular}

Table 5(b). Systematic Risk (Beta) of REITs (Sub-period KLPI)

\begin{tabular}{lcccccc}
\hline & \multicolumn{7}{c}{ Time Period } \\
\cline { 2 - 7 } REITs & \multicolumn{2}{c}{ Pre-crisis } & \multicolumn{2}{c}{ Crisis } & \multicolumn{2}{c}{ Post-crisis } \\
\cline { 2 - 7 } & (KLPI) & p-value & (KLPI) & p-value & (KLPI) & p-value \\
\hline AHP & 1.255 & 0.000 & 0.771 & 0.000 & 0.716 & 0.000 \\
AHP2 & - & - & 0.819 & 0.000 & 0.299 & 0.001 \\
AMFPT & 0.942 & 0.000 & 0.719 & 0.000 & 0.438 & 0.000 \\
FMPT & 1.088 & 0.000 & 1.025 & 0.000 & 0.457 & 0.016 \\
\hline Average & 1.095 & & 0.833 & 0.478 & \\
\hline
\end{tabular}

